Research Paper

\title{
Tuberostemonine reverses multidrug resistance in chronic myelogenous leukemia cells K562/ADR
}

\author{
Yu Jia Wang ${ }^{* *}$, Huan Dong Zhao ${ }^{2,3 *}$, Cai Feng Zhu ${ }^{4 *}$, Jian Li ${ }^{5}$, Hong Juan Xie ${ }^{6 凶}$, Yu Xiang Chen ${ }^{2 凶}$ \\ 1. Tongren Hospital, School of Medicine, Shanghai JiaoTong University, 1111 Xianxia Road, Changning District, Shanghai 200336, China; \\ 2. School of Pharmaceutical Sciences, Central South University, 172 Tongzipo Road, Changsha 410013, China; \\ 3. Key Laboratory of Nanobiological Technology of Chinese Ministry of Health, Xiangya Hospital, Central South University, 78 Xiangya Road, Changsha \\ 410008, China; \\ 4. School of Pharmacy, Yanbian University, 977 Park Road, Yanji 133000, China; \\ 5. Hepatobilliary and Enteric Surgery Research Center, Xiangya Hospital, Central South University, 78 Xiangya Road, Changsha 410008, China; \\ 6. Shanghai First Maternity and Infant Hospital Corporation. 2699 Gaoke West Road, Pudong New Area, Shanghai, 201204, China. \\ * These authors contributed equally to this work \\ $\triangle$ Corresponding authors: Hong-jun XIE, 2699 Gaoke West Road, Pudong New Area, Shanghai, 201204, China. Tel: +86-21-52039999-75604, \\ 1571792870@qq.com; Yu-xiang CHEN, 172 Tongzipo Road, Changsha 410013, China. Tel: +86-731-84327993; Chenyx008@aliyun.com.
}

( ) Ivyspring International Publisher. This is an open access article distributed under the terms of the Creative Commons Attribution (CC BY-NC) license (https://creativecommons.org/licenses/by-nc/4.0/). See http://ivyspring.com/terms for full terms and conditions.

Received: 2016.09.24; Accepted: 2017.02.01; Published: 2017.04.09

\begin{abstract}
Objective: To investigate the reversal effect of tuberostemonine on MDR in myelogenous leukemia cells K562/ADR.

Methods: Human myelogenous leukemia cells $\mathrm{K} 562$ and their adriamycin-resistance cells K562/ADR were used. The growth curve of cells treated by tuberostemonine and the Non-toxic concentration of tuberostemonine were determined by MTT, Cell apoptosis was determined by MTT and flow cytometry. The expression of MDR1, Survivin and Livin was detected by RT-PCR. The activity of P-gp was detected by flow cytometry. Western blot was used to detect the expression of NF-KB and Survivin.

Results: The effect of tuberostemonine on K562/ADR showed a dose-dependence, and $350 \mu \mathrm{g} / \mathrm{mL}$ and $500 \mu \mathrm{g} / \mathrm{mL}$ of tuberostemonine could inhibit the expression of MDRI $(P<0.05)$. While no function difference of $\mathrm{P}$-gP was detected. With the increased concentration of tuberostemonine, the inhibitory effect were enhanced to the expression of NF-KB. Tuberostemonine combined with adriamycin could time-dependently inhibit the cell proliferation $(\mathrm{P}<0.05)$ and obviously promoted the cell apoptosis $(\mathrm{P}<0.05)$. Also the tuberostemonine could inhibit the expression of Survivin.

Conclusion: There are no direct relations between tuberostemonine and P-gp, but tuberostemonine could reverse the multidrug resistance of K562/ADR via down-regulating the expression of Nf-KB and inhibiting thle expression of Survivin.
\end{abstract}

Key words: tuberostemonine; multidrug resistance; P-glycoprotein; K562/ ADR; apoptosis.

\section{Introduction}

MDR is one of the most important reasons for the failure of chemotherapy. Since the MDR was discovered in 1970 [1], it has been extensively studied by a multitude of medical investigators. The mechanism of MDR is extremely complicated for its multi-genes, multi-factors and multi-levels, it can be induced by different channels and one tumor cell may have different MDR mechanisms. The over expression of P-gp encoded by ABCB1 is the main cause of MDR and it almost exists in all malignant tumor cells. P-gp can reduce the drug concentration by pumping chemotherapy drugs out of cells, and it can also cause cross drug resistance [2,3]. Survivin and Livin are important factors related to apoptosis of tumor cells. 
Their overexpression can directly lead to resistance of tumor cells to chemotherapy drugs and some researches showed they could indirectly cause MDR by affecting the expression of P-gp [4-7].

Therefore, it has become a hot topic to find suitable reversal agents to overcome the MDR. TCM is the potential MDR reversal agents with the properties of multi-components, multi-targets, multi-channels and little side effects $[8,9]$.

Stemona japonica is a stemona plant that distributes in Jiangxi, Zhejiang, Jiangsu, etc. China, its extracts are most alkaloids and all have extensively pharmacological activities. In recent years, the researches have also found the extracts have good anti-tumor activities, which could serve as a P-gp inhibitor. In 2007, the first report in the world by Limtrakul et al. showed that the stemona alkaloids had the inhibitory effect on P-gp [10]. The research by Chanmahasathien et al. [8] indicated the stemona alkaloids of temofoline, oxystemokerrine and stemocurtisine could enhance the sensitivity of cervical carcinoma cells to antitumor drugs in vitro and they published a research on the mechanism of modulation of P-gp by stemofoline, which stated that the stemofoline was an effective P-gp inhibitor [11]. The recent study by Lu et al. showed that the extracts of Stemona japonica could reverse the P-gp mediated MDR of breast cancer cells MCF-7/ADR [12]. Based on the reversing P-gp mediated MDR by stemona extracts in cervical carcinoma cells, our research used the stemona extract tuberostemonine to investigate its reversal effect on the chronic myelogenous leukemia cells K562/ADR.

\section{Materials and methods}

\section{Cell lines and reagents}

Human chronic myelogenous leukemia cell line K562 and its adriamycin-resistant cell line K562/ ADR were purchased from Shanghai Meixuan Biological Science and Technology Ltd. Cells were cultured in RPMI-1640 medium (Gibco, USA) and supplemented with $10 \%$ FBS (Gibco, USA). Adriamycin was donated by Shanghai NO.6 People's Hospital. The prestained protein ladder was purchased from Thermo Co. Ltd. Western Blotting Luminol Regent was purchased from Santa Cruz Biotechnology, Inc. The developing and fixing kit was purchased from Bryotime Biotechnology. The Tween 20 was purchased from Pharmaceutical Group Co. and the Annexin V-FITC/PI kit was purchased from BD Co. USA.

\section{Cell growth assay and cytotoxicity assay}

The cells were seeded in the 96-well multiplates and $180 \mu \mathrm{L}$ about 3000 to 10000 cells each well, and cultured at $37^{\circ} \mathrm{Cin}$ an atmosphere of $5 \% \mathrm{CO}_{2}$ for $6 \mathrm{~h}$ to 24h. $20 \mu \mathrm{L}$ different concentrations of adriamycin were added then cultured for $24 \mathrm{~h}, 48 \mathrm{~h}$ and $72 \mathrm{~h}$, the supernatant was washed away afterward. $90 \mu \mathrm{L}$ RPMI-1650 and $10 \mu \mathrm{L}$ MTT $(5 \mathrm{mg} / \mathrm{mL})$ were added and incubated again for $4 \mathrm{~h}$, the supernatant was washed away, then the $150 \mu \mathrm{L}$ DMSO was added each well, and shaken for $10 \mathrm{~min}$ at a low speed and detected at $490 \mathrm{~nm}$ wavelength. The drug-resistance of K562 and K562/ADR cells and the inhibition rate of tuberostemonine to the cells were both determined by the above method.

\section{The P-gp expression assay}

\section{The MDR 1 expression assay by RT-PCR}

The cells were incubated with different concentrations of drugs for $48 \mathrm{~h}$ and $72 \mathrm{~h}$. Trizol kit was used to extract RNA, Takara kit was used to reverse transcript RNA to get cDNA fragments. The MDR1primers were 5'-GCC TGG CAG CTG GAA GAC AAA TAC-3' (sense) and 5'-ATG GCC AAA ATC ACA AGG GTT AGC-3' (antisense).

\section{The P-gP activity assay}

The experiment groups were as follows: A: K562 + Adriamycin; B: K562/ADR + Adriamycin; C: K562/ADR + 200 $\mu \mathrm{g} / \mathrm{mL}$ Tuberostemonine; D: $\mathrm{K} 562 / \mathrm{ADR}+350 \mu \mathrm{g} / \mathrm{mL}$ Tuberostemonine + Adriamycin; E: K562/ADR $+500 \mu \mathrm{g} / \mathrm{mL}$ Tuberostemonine + Adriamycin; F: K562/ADR + $5 \mu \mathrm{g} / \mathrm{mL}$ Verapamil + Adriamycin; The concentrations of adriamycin were all $2.454 \mu \mathrm{g} / \mathrm{mL}$. $4 \times 10^{5}$ cells each well, cells incubated for $24 \mathrm{~h}$ or $48 \mathrm{~h}$ after the drugs were added, then the P-gp activity was determined by flow cytometer. The process was as follows: each sample had $2 \times 10^{5}$ cells, that were washed by $1 \mathrm{~mL} 1 \%$ NBS and centrifuged at 5000rpm at $4^{\circ} \mathrm{C}$ for $5 \mathrm{~min}$, supernatant was discarded and washed for 2 to 3 times. The samples were incubated with anti-p-gp-FITC antibody for $15 \mathrm{~min}$ at room temperature and dark area. The process was repeated and finally resuspended with $200 \mathrm{uL} 1 \%$ NBS, $100 \mathrm{uL}$ or $200 \mathrm{uL}$ each well for detection.

\section{Western blot analysis of NF-KB expression}

The groups were the same as above section, and the western blot was performed as previously described [13]. Briefly, the 500ng of total protein was loaded onto the SDS-PAGE gel and transferred to PVDF membranes. After blocking with 5\% non-fat milk for $1 \mathrm{~h}$, membranes were then incubated with primary antibody overnight at $4^{\circ} \mathrm{C}$, then the membranes were incubated with HRP-labeled secondary antibody for $1 \mathrm{~h}$ at room temperature the next day. Immunoreactive proteins were detected using a chemiluminescence reagent by following the 
user manual. The primary antibody was anti-NF-kB (1:1000 dilution) the secondary antibody was sheep-anti-rabbit antibody with HRP-labeled (1:500 dilution), the GAPDH was selected as the loading control,

\section{Apoptosis assay}

\section{Apoptosis assay by MTT}

The experiment groups were as follows: A: K562 cells; B: K562 + Adriamycin; C: K562/ADR cells; D: K562/ADR + Adriamycin; E: K562/ADR + 200 $\mu \mathrm{g} / \mathrm{mL}$ Tuberostemonine; F: K562/ADR + 350 $\mu \mathrm{g} / \mathrm{mL}$ Tuberostemonine + Adriamycin; G: K562/ADR + $500 \mu \mathrm{g} / \mathrm{mL}$ Tuberostemonine + Adriamycin; H: The blank groups were culture medium, MTT and DMSO. The concentrations of adriamycin were all $2.454 \mu \mathrm{g} / \mathrm{mL}$ for each experimental group. The experiment was repeated 3 times and the MTT operational processes were the same as section 1.2

\section{Apoptosis assay by flow cytometry}

The Annexin V-FITC/PI double staining method was introduced to detect the cell apoptosis. The cells were collected after washed by PBS 2 times and centrifuged at 2000rpm for $5 \mathrm{~min}$. $500 \mu \mathrm{L}$ binding buffer was added to suspend cells, then mixed together with $5 \mu \mathrm{L}$ Annexin V-FITC and $5 \mu \mathrm{L}$ propidium iodide. The experiment was reacted for $5 \mathrm{~min}$ to $15 \mathrm{~min}$ at room temperature and dark place. The detection was carried by flow cytometry within 1 h.

\section{The expression of Survivin and Livin by RT-PCR}

The survivin primers were $5^{\prime}$ - GTC CCT GGC TCC TCT ACT GT -3' (sense) and 5'-TCT GTC TCC TCA TCC ACC TGA AG-3' (antisense). The Livin primers were 5'-ACA CAG GCC ATC AGG ACA

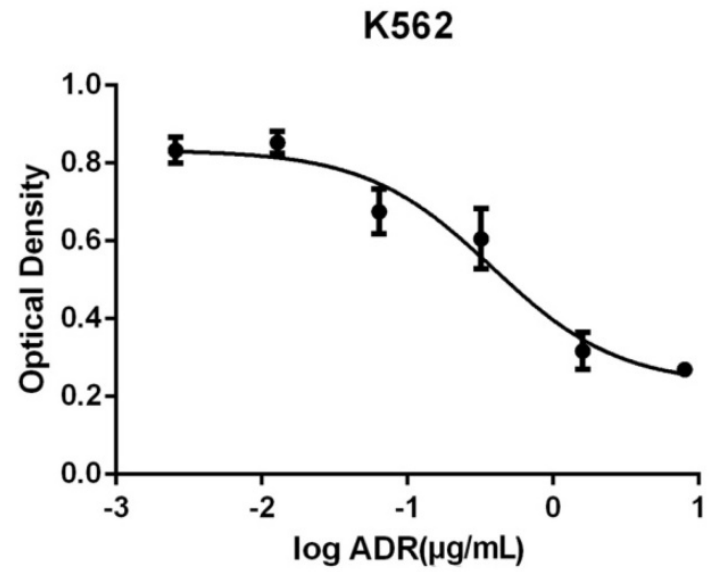

AGG TG -3' (sense) and 5'-TGA CCG GAG CAG GAA CTG ACA G -3' (antisense). The experiment was performed for $24 \mathrm{~h}$ and $48 \mathrm{~h}$ and the operational processes were the same as MDR1 assay.

\section{The expression of survivin by western blot}

The experiment processes were the same as NF-kB detection by western blot. The molecular weight of Survivin was 20KD, the primary antibody was anti-Survivin (1:100 dilution) secondary antibody was sheep-anti-mouse with HRP-labeled (1:1000 dilution). The GAPDH was selected as loading control.

\section{Statistical analysis}

Each experiment was repeated at least 3 times. The data were presented as the mean \pm SD. Differences between two groups were analyzed using t-tests, three groups were ANOVA and LSD-t-tests. Statistical significance was considered at $p<0.05$.

\section{Results}

\section{The drug-resistance properties of K562/ADR}

The OD of different concentrations of adriamycin acting on $\mathrm{K} 562$ and $\mathrm{K} 562 / \mathrm{ADR}$ is as follows (Figure 1).

The adriamycin presented a concentration-dependent manner for K562, the inhibitory effect were enhanced with the increasing of adriamycin concentrations. The $\mathrm{IC}_{50}$ figured out by Graphpad Prism was $2.454 \mu \mathrm{g} / \mathrm{mL}$. However, the adriamycin did not present a concentrationdependent manner for K562/ADR, the inhibitory effect had no significant changes with the increasing of adriamycin concentration and it did not have a certain $\mathrm{IC}_{50}$, therefore, the K562/ADR was good drug-resistance cells compared with K562.

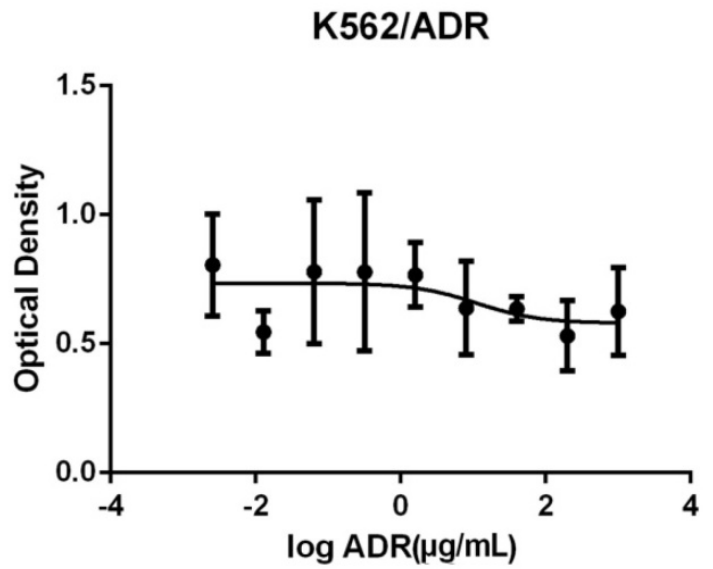

Figure 1. The changes of optical density of different concentrations of adriamycin acting on K562 (Left) and K562/ADR (Right). The abscissa represents the logarithm of the concentration of Adriamycin. 


\section{The inhibitory effect of tuberostemonine to K562 and K562/ADR}

Different concentrations of tuberostemonine were employed to investigate the inhibitory effect to K562 and K562/ADR and the results are as follows (Figure 2). It could be seen from the figure 2 that the inhibitory effect of tuberostemonine presented a concentration-dependent manner. The inhibition rate rose with the increasing of tuberostemonine concentration. It is figured out from Graphpad Prism that the $\mathrm{IC}_{50}$ was $214.7 \mu \mathrm{g} / \mathrm{mL}$ for $\mathrm{K} 562$ and $280.4 \mu \mathrm{g} / \mathrm{mL}$ for K562/ADR. Finally we selected $200 \mu \mathrm{g} / \mathrm{mL}, 350 \mu \mathrm{g} / \mathrm{mL}, 500 \mu \mathrm{g} / \mathrm{mL}$ as low, medium and high concentration of tuberostemonine, respectively.

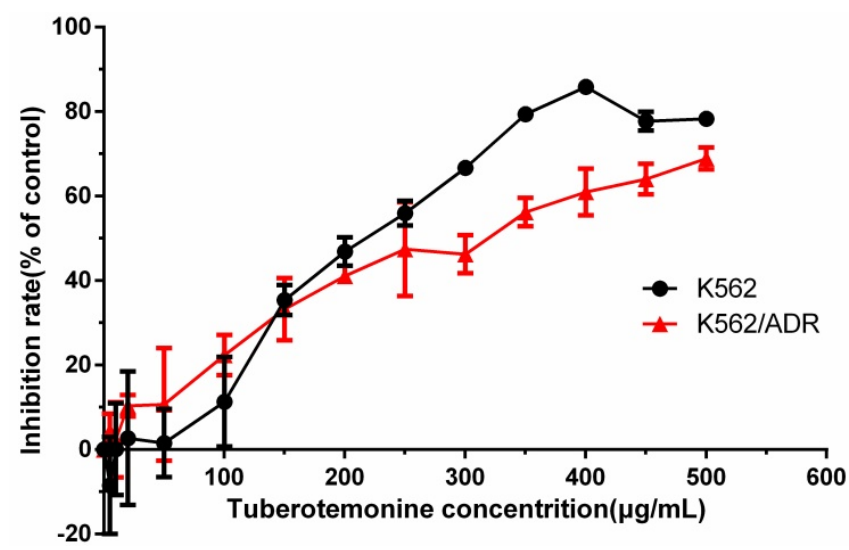

Figure 2. The inhibitory effects of different concentrations of tuberostemonine to K562 and K562/ADR.

\section{The expression of MDR 1 and the activity of P-gp}

The expression of MDR1 was obviously inhibited after cultured with the concentration of $500 \mathrm{ug} / \mathrm{mL}$ for $48 \mathrm{~h}$ and $72 \mathrm{~h}$. When the concentration was $350 \mathrm{ug} / \mathrm{mL}$, the MDR1 also could be significantly inhibited (Figure 3).

However, the results of flow cytometry indicated that tuberostemonine could not inhibit the activity of P-gp, instead the activity of P-gp was enhanced. It could be seen from the figure that after the different concentrations of tuberostemonine were added, the positive rate of P-gp didn't fall but rise. It might be related to that high concentration of tuberostemonine, which might directly cause the decrease of cytoactive or the death of tumor cells but could not influence the activity of P-gp (Figure 4).

\section{The expression of NF-KB}

The western blot result is as follows (Figure 5). It is apparently that the expression of NF- $\mathrm{kB}$ was inhibited by tuberostemonine, and the inhibitory effect to 105KD NF-kB of $300 \mu \mathrm{g} / \mathrm{mL}$ and $500 \mu \mathrm{g} / \mathrm{mLwas}$ better than $200 \mu \mathrm{g} / \mathrm{mL}$.

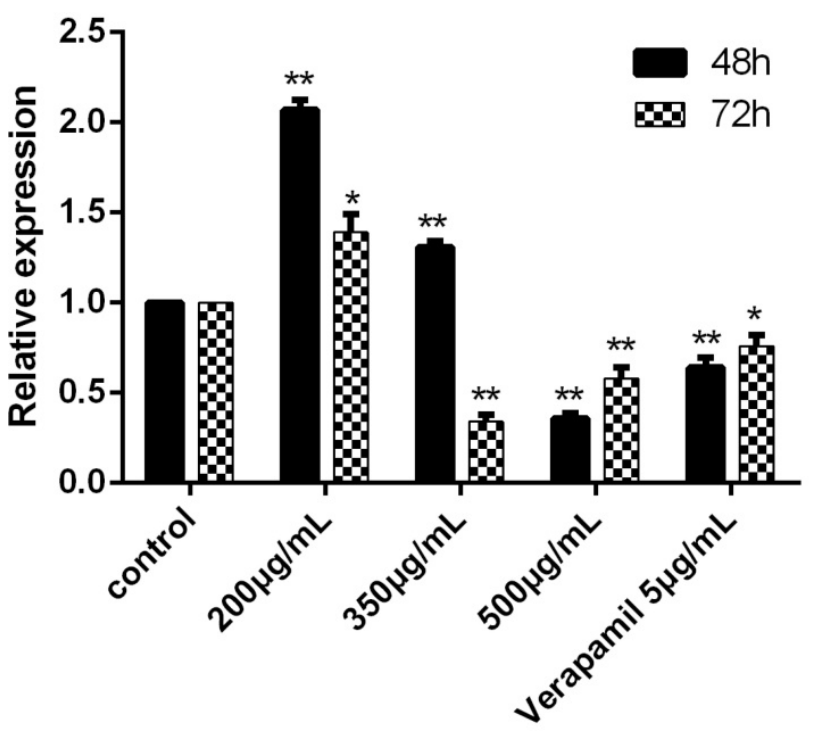

Figure 3. The expression of MDR1 determined by RT-PCR after cultured with drugs for $\mathbf{4 8 h}$ and $\mathbf{7 2 h}$. The control group was K562/ADR and the MDR1 gene of this group was reference gene, the relative expression was 1 . In other groups, the relative expression would be determined after the $\mathrm{Ct}, \Delta \mathrm{Ct}$ and $\Delta \Delta \mathrm{Ct}$ were figured put. $* \mathrm{P}<0.05$ vs control group, $* * \mathrm{P}<0.01$ vs. control group.

\section{Cell apoptosis assay by MTT}

The experiment was divided into 7 groups, given different treatments. Three time points were detected to investigate the proapoptosis of tuberostemonine to K562/ADR. The MTT results are as follows (Table 1). It was obvious that the tuberostemonine could promote the cell apoptosis and there was significant difference between the low, medium, high concentration groups and the control group with no tuberostemonine $(\mathrm{P}<0.05)$. It could be seen that the inhibitory effect of the same concentration of tuberostemonine to K562/ADR presented a time-dependence. There was significant difference among the different concentrations at the same time $(\mathrm{P}<0.01)$. The LSD-t test showed no significant difference between $200 \mathrm{ug} / \mathrm{mL}$ and $350 \mathrm{ug} / \mathrm{mL}$ at $72 \mathrm{~h}$ $(\mathrm{P}>0.05)$ but there was significant difference among groups treated with three concentrations at the same time point $(\mathrm{P}<0.05)$ (Figure 6$)$. MTT reveals the proapoptosis effect of tuberostemonine combined with adriamycin was stronger than adriamycin alone (Figure 7).

The results of cell apoptosis after $24 \mathrm{~h}$ were as follows (Figure 8): The proapoptosis effect of K562/ADR treated with tuberostemonine and adriamycin (Figure $8 \mathrm{BCD}$ ) were stronger than treated with adriamycin alone (Figure $8 \mathrm{~A}$ ). The experiment selected the $5 \mu \mathrm{g} / \mathrm{mL}$ verapamil as the positive control 
group (Figure $8 \mathrm{E}$ ) and the result showed that the proapoptosis effect of verapamil combined with

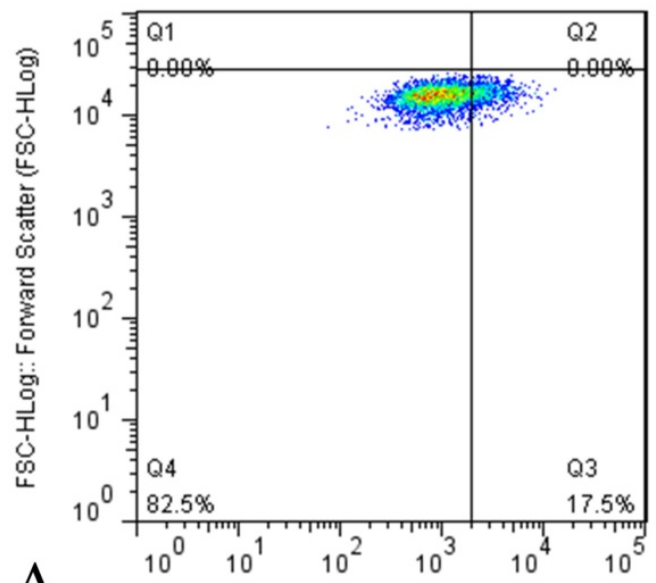

A

GRN-B-HLog:: Green-B Fluorescence (GRN-B-HLog)

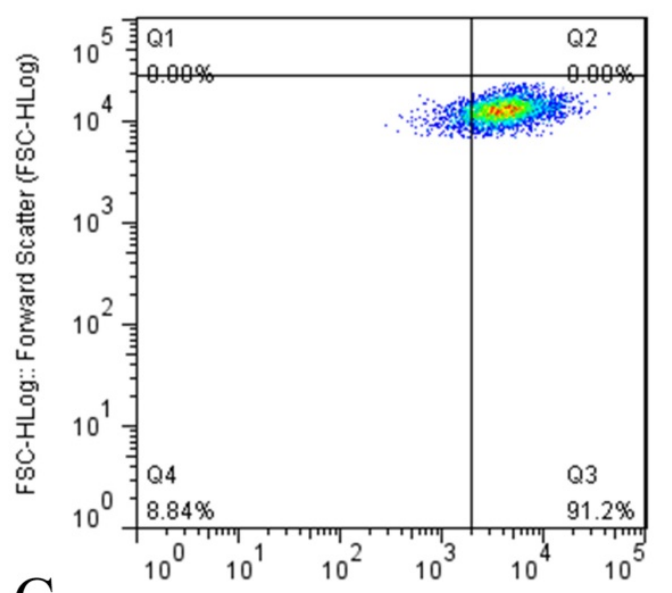

GRN-B-HLog:: Green-B Fluorescence (GRN-B-HLog)

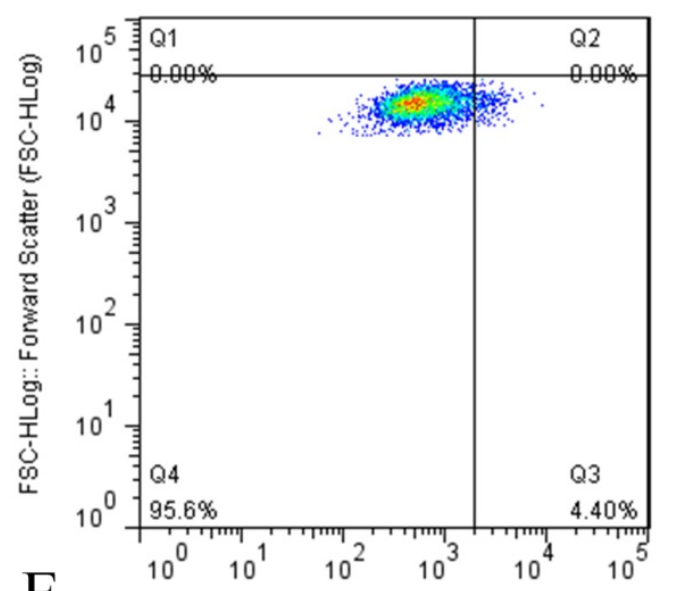

$\mathrm{E}$

GRN-B-HLog:: Green-B Fluorescence (GRN-B-HLog) adriamycin were stronger than group $\mathrm{A}$ but weaker than group $\mathrm{B}, \mathrm{C}$ and $\mathrm{D}$.

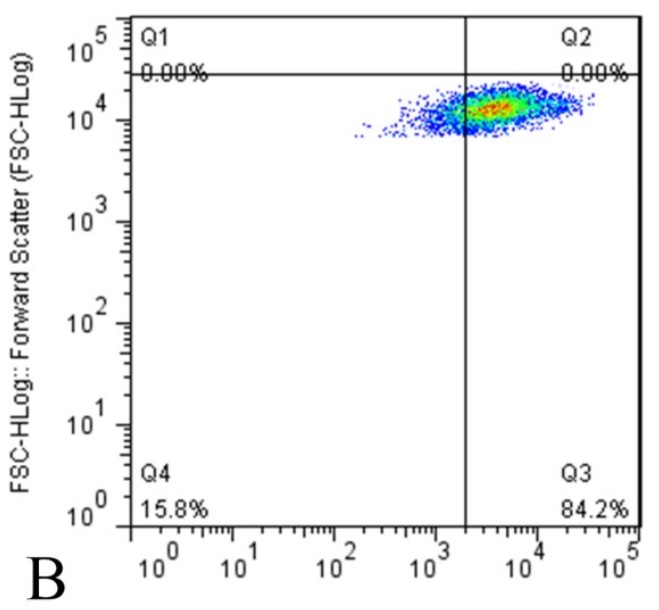

GRN-B-HLog:: Green-B Fluorescence (GRN-B-HLog)

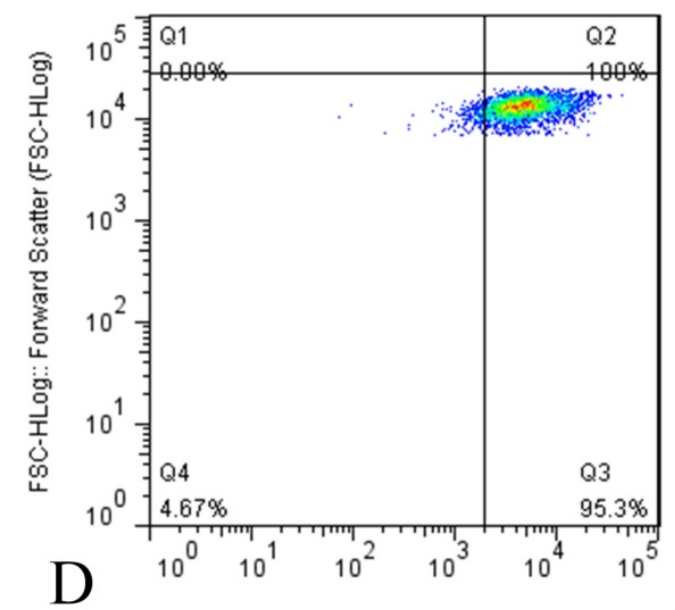

GRN-B-HLog:: Green-B Fluorescence (GRN-B-HLog)

Figure 4. The P-gp activity detected by flow cytometry. The abscissa Green-B Fluorescence intensity represents the FITC staining. and the ordinate Forward

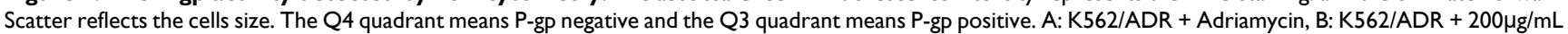

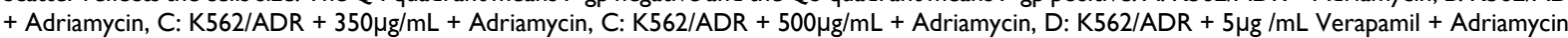


K562/ADR K562/ADR+ADR $\quad 200 \mu \mathrm{g} / \mathrm{mL} \quad 350 \mu \mathrm{g} / \mathrm{mL} \quad 500 \mu \mathrm{g} / \mathrm{mL} \quad 5 \mu \mathrm{g} / \mathrm{mL}$ Vrapamil

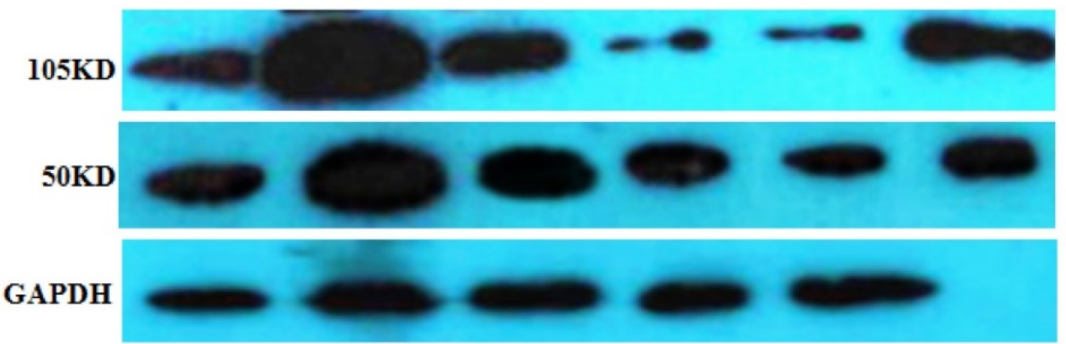

Figure 5. The expression of NF-KB detected by western blot. The reference protein was GAPDH, but the membrane was broken at brood membranes, so that the last stripe could not be seen after developing.

Table 1. The effects of different tuberostemonine to the optical density (OD) of K562 and K562/ADR

\begin{tabular}{|c|c|c|c|}
\hline \multirow[t]{2}{*}{ Group } & \multicolumn{3}{|c|}{ OD value $\left(\times 10^{-2}\right)$} \\
\hline & $24 \mathrm{~h}$ & $48 \mathrm{~h}$ & $72 \mathrm{~h}$ \\
\hline K562 & $36.67 \pm 0.57$ & $65.77 \pm 1.32$ & $88.93 \pm 1.10$ \\
\hline K562+ADR & $31.90 \pm 1.40^{\#}$ & $49.17 \pm 0.25^{\#}$ & $41.30 \pm 1.25^{\#}$ \\
\hline K562/ADR & $25.10 \pm 1.90$ & $38.30 \pm 2.62$ & $54.80 \pm 1.30$ \\
\hline K562/ADR+ADR & $23.43 \pm 0.15$ & $31.40 \pm 0.46^{\Delta}$ & $47.33 \pm 0.42 \triangle$ \\
\hline $\mathrm{K} 562 / \mathrm{ADR}+200 \mu \mathrm{g} / \mathrm{mL}+\mathrm{ADR}$ & $17.53 \pm 1.81^{*}$ & $17.90 \pm 0.26^{*}$ & $18.33 \pm 0.40^{*}$ \\
\hline $\mathrm{K} 562 / \mathrm{ADR}+350 \mu \mathrm{g} / \mathrm{mL}+\mathrm{ADR}$ & $20.13 \pm 1.20^{*}$ & $20.46 \pm 0.84^{*}$ & $18.50 \pm 0.44^{*}$ \\
\hline $\mathrm{K} 562 / \mathrm{ADR}+500 \mu \mathrm{g} / \mathrm{mL}+\mathrm{ADR}$ & $22.80 \pm 1.01$ & $24.77 \pm 0.45^{*}$ & $23.10 \pm 0.46^{*}$ \\
\hline
\end{tabular}

Note: OD: Optical density. \#P<0.05 vs. group K562, $\triangle \mathrm{P}<0.05$ vs. group

$\mathrm{K} 562 / \mathrm{ADR},{ }^{*} \mathrm{P}<0.05$ vs. group K562/ADR+ADR

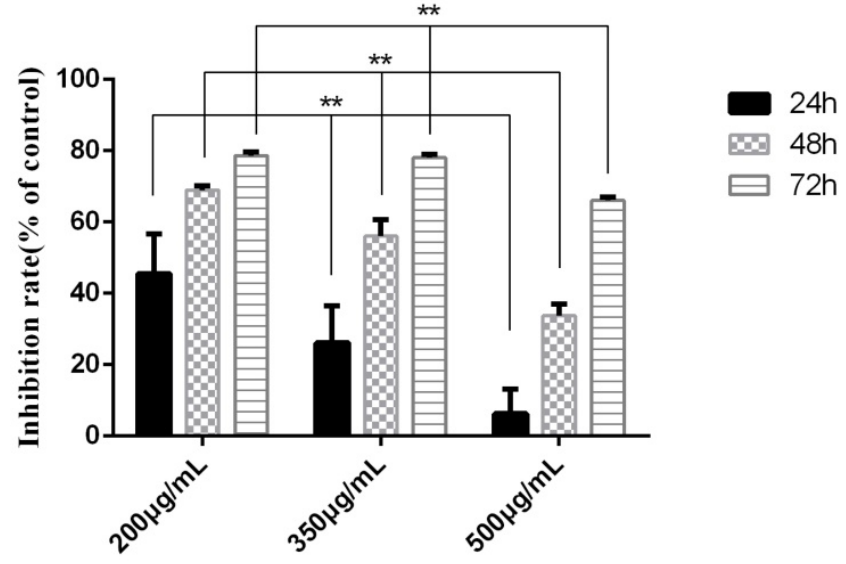

Figure 6. The inhibition rate of tuberostemonine on K562/ADR. The abscissa represents the different concentrations of tuberostemonine. ${ }^{* *} \mathrm{p}<0.01$ means there is significant difference in groups treated with different concentration of tuberostemonine at the same time point.

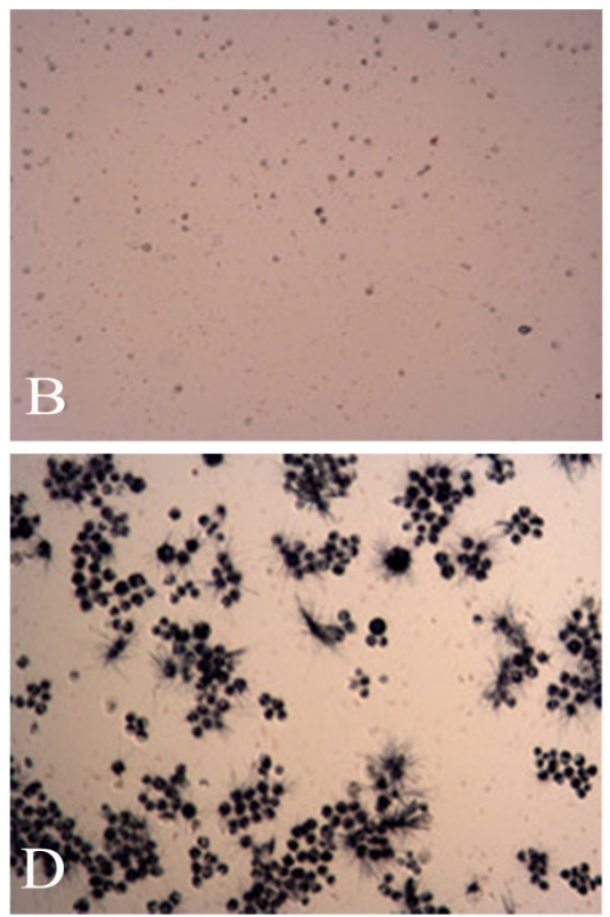

Figure 7. The MTT pictures of proapoptosis effects of tuberostemonine combined with adriamycin and Adriamycin alone. A: K562/ADR +

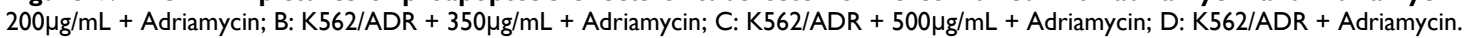




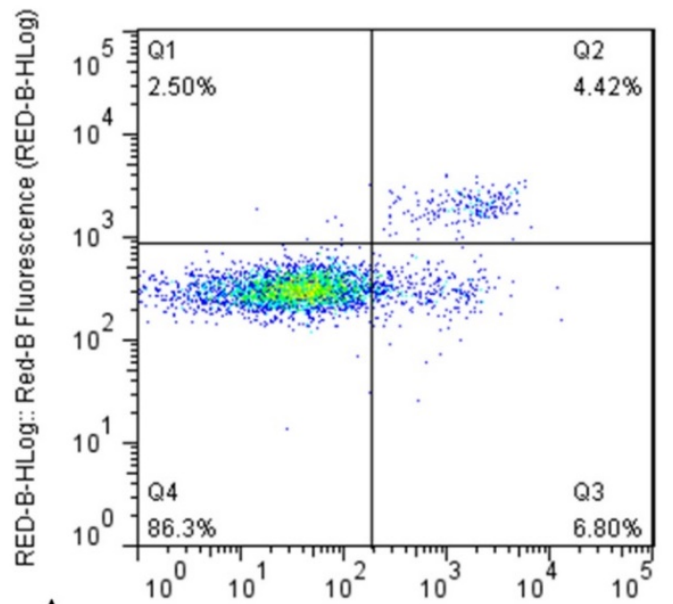

A

GRN-B-HLog:: Green-B Fluorescence (GRN-B-HLog)
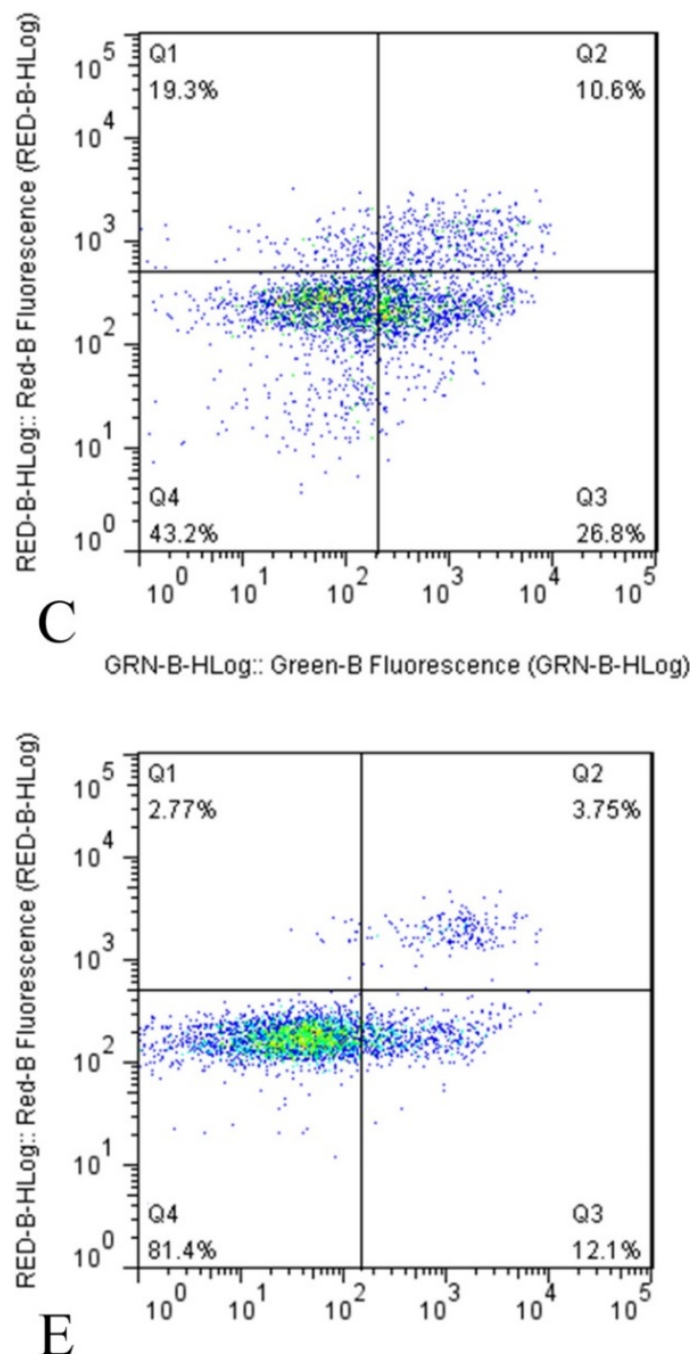

GRN-B-HLog:: Green-B Fluorescence (GRN-B-HLog)

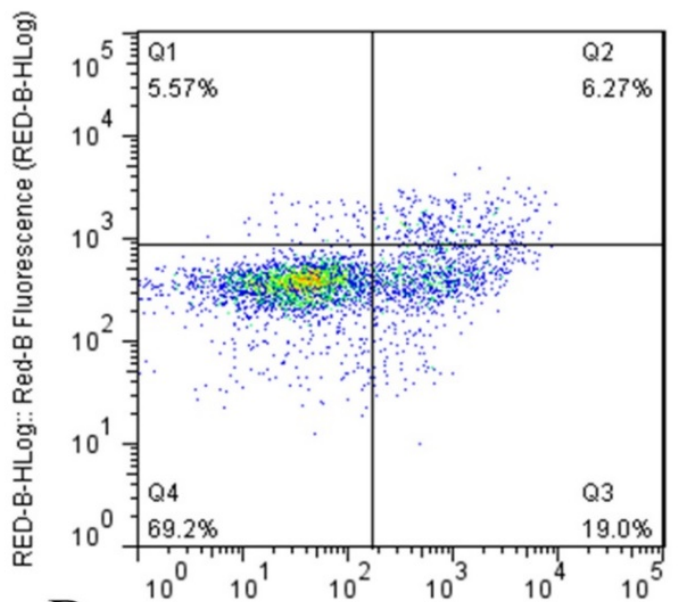

$\mathrm{B}$

GRN-B-HLog:: Green-B Fluorescence (GRN-B-HLog)

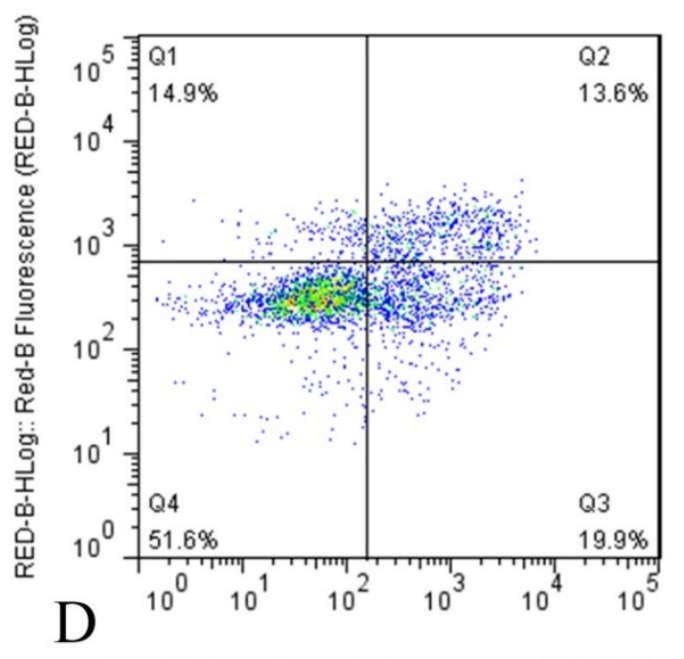

GRN-B-HLog:: Green-B Fluorescence (GRN-B-HLog)

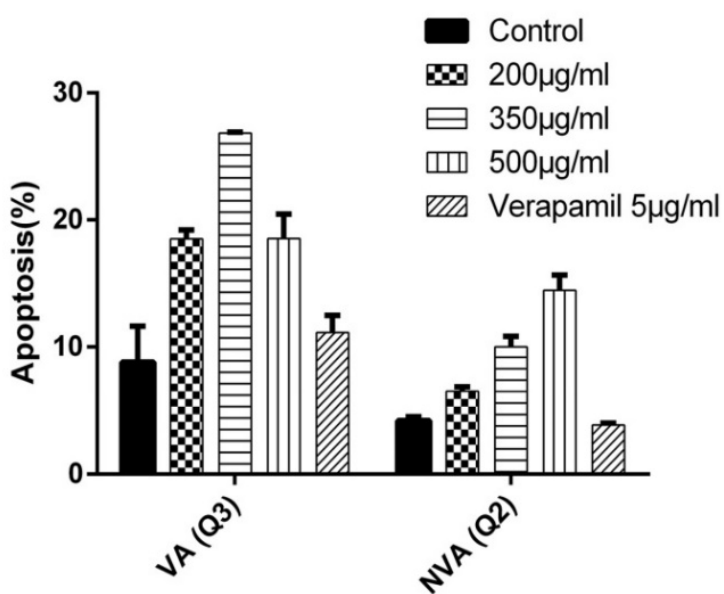

Figure 8. The apoptosis results by flow cytometry after $\mathbf{2 4 h}$. The abscissa Green-B Fluorescence intensity represents the FITC staining. and the ordinate Red-B Fluorescence intensity represents the PI staining. The Q1 for necrotic cells, Q2 for quadrant for non-viable apoptotic cells (NVA), Q3 for viable apoptotic cells

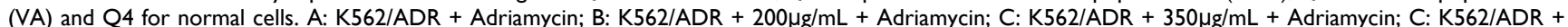

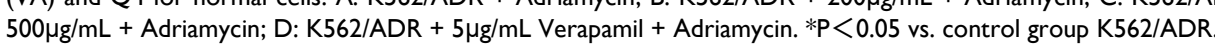




\section{The expression of Survivin and Livin by RT-PCR}

The results showed that the relative expression of Livin each group was 0 , that is to say, the reverse effect of tuberostemonine were not related to Livin. We could see that the expression of Survivin was effectively down-regulated by tuberostemonine. In the result at 24h, the expression of Survivin was decreased with the concentration increased of tuberostemonine. However, the results at $48 \mathrm{~h}$ were the opposite to $24 \mathrm{~h}$. And in the groups of $350 \mu \mathrm{g} / \mathrm{mL}$ and $500 \mu \mathrm{g} / \mathrm{mL}$, the expression of Survivin was up-regulated; the mechanism needs further study (Figure 9).

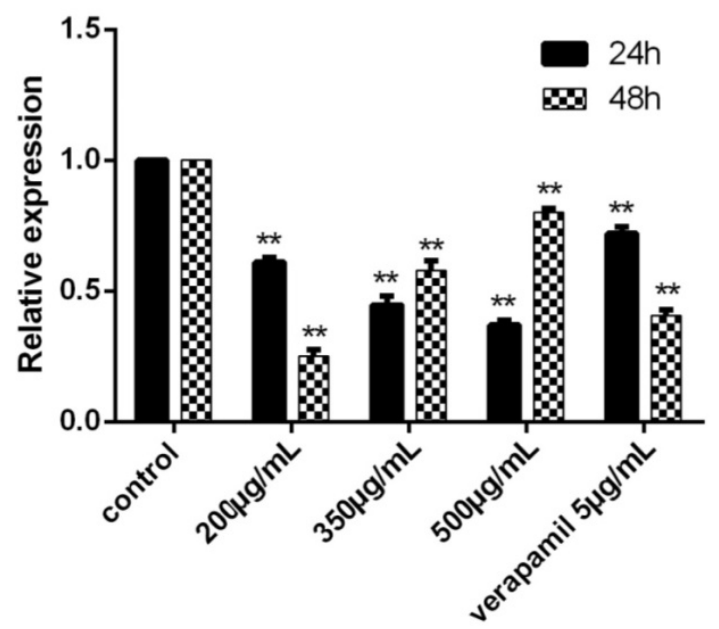

Figure 9. The expression of Survivin after cultured $24 \mathrm{~h}$ and $48 \mathrm{~h}$ detected by RT-PCR. The control group was K562/ADR, and the Survivin in this group was selected as the reference gene, its relative expression was 1 . The relative expression of other groups could be determined after the $\mathrm{Ct}, \Delta \mathrm{Ct}$ and $\Delta \Delta \mathrm{Ct}$ were figured out. ${ }^{* * \mathrm{P}}<0.01$ vs. control group.

\section{The expression of Survivin by western blot}

The result indicated that the expression of Survivin was apparently down-regulated by different concentrations of tuberostemonine pointed out that the MDR of K562/ADR might be related to the Survivin (Figure 10).

\section{Discussion}

MDR is one of the major problems in leukaemia therapy, it is very important to reverse the MDR of leukaemia and improve the prognosis and survival rate of patients.

The overexpression of P-gp is one of the most important reasons for MDR, and the NF- $\mathrm{KB}$ is a vital factor to regulate the inflammation and the cell proliferation. It also participates in the regulation of apoptotic genes and is responsible for the survival of tumor cells, which is closely related to the MDR [14, 15]. NF-kB can activate the transcription of ABCB1/MDR1 to up-regulate the expression of P-gp, enhancing the MDR of tumor cells [16]. Livin and Survivin, as the important members of the family of IAPs, are highly expressed in many malignant tumors, which are closely related to the apoptosis of tumor cells. Researches have pointed out that the Survivin and Livin were overexpressed in human acute lymphatic leukemia which is related to the occurrence and development of the disease, therefore, they play an important role in the MDR of leukemia $[17,18]$.

Early in 1970s, researchers had focused on how to reverse the MDR, the first generation of reversal agents with the representative of verapamil, was mainly aimed at the MDR mediated by P-gp, which reversed MDR via competitive combining with $\mathrm{P}$-gp, but the side effect and the toxicities were intensive. Many natural medicine and Chinese herbal medicine can overcome the problems and have showed great advantages in reversing MDR. It has been reported that the extracts like peoniflorin, curcumin and procyanidin etc. could effectively inhibit the activity of NF- $\mathrm{kB}$, down-regulate the expression of ABCB1 and decrease the P-gp expression [19-23]. In our works, we have employed the extract of Traditional Chinese Medicine Stemona japonica, tuberostemonine as the MDR reversal agent, to study its reversal effect on myelogenous leukemia adriamycin-resistance cells K562/ADR. There were no similar literatures about the inhibitory effect of the stemona extracts on the P-gp of human leukemia cells and the toxicities to leukemia cells, also the enhancement on the chemotherapy drugs for leukemia cells both home and abroad.

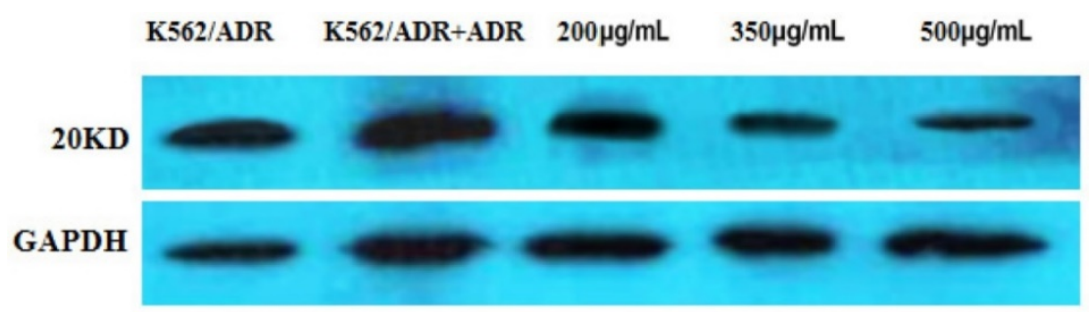

Figure 10. The expression of the 20KD Survivin detected by western blot. The reference protein is GADPH. 
This study was divided into three parts, first the cytotoxicities of tuberostemonine on human leukemia resistance cells K562/ADR, second the anti-proliferation and proapoptosis effect of tuberostemonine combined with adriamycin on K562/ADR and the last the influences of tuberostemonine on the MDR genes and proteins like MDR1, P-gp, NF-kB, Livin and Survivin. The inhibitory effect of tuberostemonine presented a concentration-dependent manner and the $\mathrm{IC}_{50}$ of the tuberostemonine to $\mathrm{K} 562$ and $\mathrm{K} 5562 / \mathrm{ADR}$ was $214.7 \mu \mathrm{g} / \mathrm{mL}$ and $280.4 \mu \mathrm{g} / \mathrm{mL}$, we selected $200 \mathrm{ug} / \mathrm{mL}, 350 \mathrm{ug} / \mathrm{mL}$ and $500 \mathrm{ug} / \mathrm{mL}$ as the low, medium and high concentrations through studying the cytotoxicities of different concentrations of tuberostemonine on K562/ADR. The three concentrations of tuberostemonine had the inhibitory effect on K562/ADR cultured with adriamycin and a time-dependence manner was presented at the same concentration of tuberostemonine, but with the increasing of concentration of tuberostemonine, the inhibitory effect decreased. It was different from the results of tuberostemonine alone acting on the $\mathrm{K} 562 / \mathrm{ADR}$, it indicated that the proapoptosis effect of tuberostemonine cultured with adriamycin didn't enhanced with the concentration increased, instead the high concentration of tuberostemonine was weaker. From the apoptosis result by flow cytometry, we could also find that the inhibitory effect of high concentration of tuberostemonine were not preferable, and it could be seen from the Q1 quadrant that the necrotic cells became more as the concentration increased. In a word, the best concentration might be between $200 \mu \mathrm{g} / \mathrm{mL}$ and $350 \mu \mathrm{g} / \mathrm{mL}$. RT-PCR results showed the tuberostemonine could inhibit the expression of MDR1, and the inhibitory effect was positively correlated with the concentrations. The flow cytometry assay indicated that the three concentrations of tuberostemonine did not inhibit the activity of P-gp, we inferred that the result might be due to that high concentration of tuberostemonine $(350 \mu \mathrm{g} / \mathrm{mLand} 500 \mu \mathrm{g} / \mathrm{mL})$ significantly reduced the cytoactive even led to death, which brought the result that MDR1 gene was inhibited but the P-gp, as a protein, was not affected by the cell death. In summarize, the certain mechanism of this contradictory phenomena will be one of foci in our further study. All the concentrations of tuberostemonine had the inhibitory effect on NF-kB, and the inhibitory effect were obviously stronger than $5 \mu \mathrm{g} / \mathrm{mL}$ Verapamil, therefore, our results suggested that the tuberostemonine might reverse the MDR by inhibiting the activity of NF-kB.The RT-PCR and the western blot results showed different concentrations of tuberostemonine could down-regulate the expression of Survivin. From the western blot result, it was apparently that with the increase of the concentrations of tuberostemonine, the expression of Survivin was significantly decreased. From the RT-PCR result, the inhibitory effect was different with the same concentration at different incubation time. The inhibitory effect was enhanced with the concentration increased cultured for $24 \mathrm{~h}$ but it was opposite for $48 \mathrm{~h}$. We considered high concentration of tuberostemonine $(350 \mu \mathrm{g} / \mathrm{mL}$ and $500 \mu \mathrm{g} / \mathrm{mL})$ might have strong inhibitory action on Survivin within $24 \mathrm{~h}$, and as time went on, the cytoactive was affected, even dead, which resulted in the expression of Survivin was no more affected by tuberostemonine. This phenomenon indicated that there might be relations between the MDR of K562/ADR and Survivin, and the tuberostemonine could reverse the MDR by inhibiting the expression of Survivin. But the mechanism needed to be further investigated.

The molecular mechanism of tuberostemonine on culture cells is still a question. Here we speculate that the inhibitory effect of the tuberostemonine to cells may be due to its inhibition on the synthesis of DNA, RNA and proteins of tumor cells, and then led to cell death. Survivin and Livin are closely related to the down-regulation of caspase-3, csapase-7 and caspase-9, which play an important role in cell apoptosis [24], we inferred the tuberostemonine may protect the activity of caspase-3, caspase-7 and caspase-9 from the Survivin and Livin by down-regulating their expression. Normally, NF-kB binding to IKB could form an inactive complex, the chenmotherapeutic action on the tumor cells can lead to the activation of NF-KB and thus inhibit the cell apoptosis [25]. We supposed that tuberostemonine might down-regulate the expression of NF-kB by acting on the NF-kB: IкB complex, consequently, the chenmotherapeutic could successfully kill the tumor cells.

In conclusion, the reversal effect of tuberostemonine on K562/ADR was not directly related to P-gp, it could reverse the MDR by down-regulating the expression of NF- $\mathrm{KB}$ and inhibiting the expression of Survivin. When the concentration of tuberostemonine was between $200 \mu \mathrm{g} / \mathrm{mL}$ and $300 \mu \mathrm{g} / \mathrm{mL}$, it had good reversal effects. The tuberostemonine could be a reversal agent for the of leukemia therapy, which can reduce the occurrence of MDR in leukemia chemotherapy and improve the efficiency of leukemia chemotherapy and prolong the life time of leukemia patients. Our study might provide a new prospect for leukamia therapy. 


\section{Abbreviations}

MDR: multidrug resistance; P-gp: P-glycoprotein; TCM: traditional Chinese medicine; ADR: Adriamycin; DMSO: dimethylsulfoxide; ANOVA: one-way analysis of variance; OD: optical density; FITC: fluorescein isothiocyanate; PI: Propidium Iodide GAPDH: glyceraldehyde-3phosphate dehydrogenase; NVA: non-viable apoptotic cells; VA: viable apoptotic cells; IAPs: inhibitor of apoptosis proteins; IкB: inhibitor-K binding protein.

\section{Acknowledgements}

This study was supported by the Project of Science and Technology Committee of Changning District, Shanghai (CNKW2013F01) and the Health and Family Planning Committee of Changning District, Shanghai (20144Y005), Hunan Provincial Nature Science Foundation (16JJ3056).

\section{Competing Interests}

The authors have declared that no competing interest exists.

\section{References}

1. Biedler JL, Riehm H: Cellular resistance to actinomycin D in Chinese hamster cells in vitro: cross-resistance, radioautographic, and cytogenetic studies. Cancer Res 1970;30:1174-1184.

2. Bayet C, Fazio C, Darbour N: Modulation of P-glycoprotein activity by acridones and coumarins from Citrus sinensis. Phytother Res 2007;21:386-390.

3. Gottesman MM, Pastan IH: The Role of Multidrug Resistance Efflux Pumps in Cancer: Revisiting a JNCI Publication Exploring Expression of the MDR1 (P-glycoprotein) Gene. J Natl Cancer Inst 2015;107.

4. Wang L, Zhang GM, Feng ZH: Down-regulation of survivin expression reversed multidrug resistance in adriamycin-resistant HL-60/ADR cell line. Acta Pharmacol Sin 2003;24:1235-1240.

5. Liu F, Xie ZH, Cai GP: The effect of survivin on multidrug resistance mediated by P-glycoprotein in MCF-7 and its adriamycin resistant cells. Biol Pharm Bull 2007;30:2279-2283

6. Wang $\mathrm{X}, \mathrm{Xu} \mathrm{J}, \mathrm{Ju}$ S: Livin gene plays a role in drug resistance of colon cancer cells. Clin Biochem 2010;43:655-660.

7. Liu F, Liu S, He S: Survivin transcription is associated with P-glycoprotein/MDR1 overexpression in the multidrug resistance of MCF-7 breast cancer cells. Oncol Rep 2010;23:1469-1475.

8. Chanmahasathien W, Ampasavate C, Greger H: Stemona alkaloids, from traditional Thai medicine, increase chemosensitivity via P-glycoprotein-mediated multidrug resistance. Phytomedicine 2011;18:199-204.

9. Li C, Sun BQ, Gai XD: Compounds from Chinese herbal medicines as reversal agents for P-glycoprotein-mediated multidrug resistance in tumours. Clin Transl Oncol 2014;16:593-598.

10. Limtrakul P, Siwanon S, Yodkeeree S: Effect of Stemona curtisii root extract on P-glycoprotein and MRP-1 function in multidrug-resistant cancer cells. Phytomedicine 2007;14:381-389.

11. Chanmahasathien W, Ohnuma S, Ambudkar SV: Biochemical mechanism of modulation of human P-glycoprotein by stemofoline. Planta Med 2011;77:1990-1995.

12. Han L, Ma YM, An L: Non-alkaloids extract from Stemona sessilifolia enhances the activity of chemotherapeutic agents through P-glycoprotein-mediated multidrug-resistant cancer cells. Nat Prod Res 2016;30:1186-1189.

13. Zhou J, Wu S, Chen Y: microRNA-143 is associated with the survival of ALDH1+CD133+ osteosarcoma cells and the chemoresistance of osteosarcoma. Exp Biol Med (Maywood) 2015;240:867-875.

14. Aggarwal BB: Nuclear factor-kappaB: the enemy within. Cancer Cell 2004:6:203-208.

15. Aggarwal BB, Shishodia S, Takada Y: Curcumin suppresses the paclitaxel-induced nuclear factor-kappaB pathway in breast cancer cells and inhibits lung metastasis of human breast cancer in nude mice. Clin Cancer Res 2005;11:7490-7498.
16. Zhou G, Kuo MT: NF-kappaB-mediated induction of mdr1b expression by insulin in rat hepatoma cells. J Biol Chem 1997;272:15174-15183.

17. Li WQ, Li XL, Wang GP: [Gene expression of livin and survivin in adult patients with acute lymphoblastic leukemia and its clinical significance]. Zhongguo Shi Yan Xue Ye Xue Za Zhi 2011;19:921-925.

18. Gu J, Ren L, Wang X: Expression of livin, survivin and caspase-3 in prostatic cancer and their clinical significance. Int J Clin Exp Pathol 2015;8:14034-14039.

19. Fang S, Zhu W, Zhang Y: Paeoniflorin modulates multidrug resistance of a human gastric cancer cell line via the inhibition of NF-kappaB activation. Mol Med Rep 2012;5:351-356.

20. Zhao BX, Sun YB, Wang SQ: Grape seed procyanidin reversal of p-glycoprotein associated multi-drug resistance via down-regulation of NF-kappaB and MAPK/ERK mediated YB-1 activity in A2780/T cells. PLoS One 2013;8:e71071.

21. Simoni D, Rizzi M, Rondanin R: Antitumor effects of curcumin and structurally beta-diketone modified analogs on multidrug resistant cancer cells. Bioorg Med Chem Lett 2008;18:845-849.

22. Ganta S, Amiji M: Coadministration of Paclitaxel and curcumin in nanoemulsion formulations to overcome multidrug resistance in tumor cells. Mol Pharm 2009;6:928-939.

23. Gou Q, Liu L, Wang C: Polymeric nanoassemblies entrapping curcumin overcome multidrug resistance in ovarian cancer. Colloids Surf B Biointerfaces 2015;126:26-34.

24. Wang $\mathrm{X}, \mathrm{Xu} \mathrm{J}, \mathrm{Ju} \mathrm{S}$ : Livin gene plays a role in drug resistance of colon cancer cells. CLINICAL BIOCHEMISTRY 2010;43:655-660.

25. Godwin P, Baird AM, Heavey S: Targeting nuclear factor-kappa B to overcome resistance to chemotherapy. Front Oncol 2013;3:120. 